\title{
A Homage to Civil Society? Literary Responses to Germany's Refugee Crisis by Jenny Erpenbeck and Bodo Kirchhoff
}

\author{
Alexandra Ludewig \\ The University of Western Australia \\ alexandra.ludewig@uwa.edu.au
}

\begin{abstract}
Although Angela Merkel refused to close Germany's borders in 2015 when faced with thousands of migrants, her response to this humanitarian crisis made shortfalls in EU policies abundantly apparent. It became obvious that the Schengen Agreement, and the Dublin Regulations were no longer workable in view of a global movement of people that had not been experienced on such a scale since the end of World War Two. Literary greats, Jenny Erpenbeck and Bodo Kirchhoff, have dealt with the related challenges emerging for civil society in Germany and elsewhere in Europe. Their protagonists' responses to encounters with refugees and irregular migrants serve as a litmus test for dominant values of the middle class and a truly civil society. My contribution suggests that literary representations of German middle-class encounters with refugees explore aspects of civil society during the European migrant crisis, illustrating gaps and failures in German and EU policy.
\end{abstract}

Keywords: Civil society, Dublin II, Erpenbeck, Germany, Kirchhoff, refugees

In September 2015, when faced with thousands of migrants marching along an autobahn in Hungary towards what they hoped would be a better future, Angela Merkel refused to close Germany's borders. ${ }^{1}$ But she did not 'invite' them into Germany, nor did she 'open' the borders. She simply upheld one of the principles guiding internal EU practices: the free movement of peoples, goods and services. Germany's response to this humanitarian crisis made shortfalls in basic EU policies more than apparent. Indeed, in view of the global movement of people, which was on a scale that had not been experienced since the end of the Second World War, it became obvious that the Schengen Agreement and the Dublin Regulations were no longer workable. Two major contemporary German writers, Jenny Erpenbeck and Bodo Kirchhoff, have dealt with the challenges emerging for civil society in Germany and elsewhere in Europe in their bestselling works: Gehen, Ging, Gegangen / Going, went, gone (2015) and

\footnotetext{
1 'Merkel's historic decision, as the investigations conducted by ZEIT and ZEIT ONLINE demonstrate, was no spontaneous humanitarian impulse, no emotional resolution, nor was it moral hubris. In the space of barely three hours and under great pressure, Merkel was forced to make the decision after Viktor Orbán had managed to put her into a position which gave her almost no alternative. It is possible that historians may one day be able to show that this dramatic situation could only have come about through the breakdown of communication within the European Union, because Brussels, Berlin and Budapest were engaged in blaming each other instead of showing solidarity, and because each one insisted that they were legally in the right, although the laws concerned had long since lost their regulatory function. Yet even today one thing can be said with some certainty: if the refugees hadn't decided on the morning of 4 September (2015) to march off from the main train station in Budapest in the direction of Vienna, the history of Europe on that weekend would have turned out quite differently.' http://www.zeit.de/2016/35/grenzoeffnung-fluechtlinge-september-2015-wochenende-angela-merkel-ungarnoesterreich/seite-6 (last accessed on 22 September 2017).
} 
Widerfahrnis / Encounter (2016). I interpret the protagonists' responses to their encounters with refugees as a litmus test for the dominant German middle-class values and for a truly civil(ised) society, while also seeing this as a moment in history where literature can help in cultivating empathy and moral imagination. Working with Schwartz's theory of values ${ }^{2}$ and Grayling's understanding of civil democracies, ${ }^{3}$ this paper suggests that literary representations of German middle-class encounters with refugees explore aspects of civil society in practice during the European migrant crisis, and that civic engagement between Germans and refugees illustrates gaps and failures in German and EU policy.

In view of what Geuijen et al. (2017) called a 'global wicked problem'-a complex issue involving intricate interactions of agencies - the protagonists in both art-mirroring-life texts are called to action by deeply held values. ${ }^{4}$ Schwartz's theory of values describes and analyses the moral and ethical convictions that are popularly held by a community and that motivate an individual's personal and social behaviour. According to Schwartz, several factors influence a person, including issues concerning their desire for or interest in power, security, tradition, benevolence or hedonism. ${ }^{5}$ In the case of Germany's broad middle-class-based civil society, trust in people's adherence to shared values has been strong, as acknowledged by Timothy Garton-Ash. ${ }^{6}$ It is not surprising then, that in the literature which tries to hold a mirror up to this society, goodness is shown to triumph over hedonism, tradition and self-interest, and somewhat implausibly, to motivate pensioners to acts of civil disobedience.

The retired intellectuals at the centre of each of these two novels, an emeritus professor of classics socialised in East Germany and a retired book-publisher from the West, share many values and educational achievements. Yet they react very differently to social challenges and are conflicted within themselves, thus embodying the feelings of many in today's Germany. They are, however, united in that when their understanding of where laws and the international community fail, their own humanity and values are first called into question and then to action.

Jenny Erpenbeck's novel Going, went, gone hit the German book market in September 2015, several months after the right-wing PEGIDA demonstrations in Saxony's capital Dresden saw record numbers of protesters chanting anti-Islamic and anti-migration slogans and less than one month prior to the historic day in Hungary, when thousands of asylum seekers decided to march towards Vienna and ultimately Germany. Over the coming weeks and months, the German public was confronted with the very visible presence of people in need on a large scale and, not unlike Erpenbeck's protagonist,

\footnotetext{
${ }^{2}$ Shalom H. Schwartz, 'An Overview of Schwartz Theory of Basic Values', Online Readings in Psychology and Culture, 2.1 (2012), available at http://scholarworks.gvsu.edu/cgi/viewcontent.cgi?article=1116\&context=orpc (last accessed on 20 September 2017) pp.2-20; here p.9.

3 Anthony C. Grayling, Liberty in the Age of Terror: A Defence of Civil Society and Enlightenment Values, London: Bloomsbury, 2009; and A. C. Grayling, Democracy and Its Crisis, London: One World Publishing 2017.

4 Karin Geuijen, Mark Moore, Andrea Cederquist, Rolf Ronning \& Mark van Twist, 'Creating public value in global wicked problems', Public Management Review, 19:5 (2017); pp.621-639; here p. 623.

5 Shalom H. Schwartz, 'An Overview of Schwartz Theory of Basic Values', Online Readings in Psychology and Culture, 2.1 (2012), available at http://scholarworks.gvsu.edu/cgi/viewcontent.cgi?article=1116\&context=orpc (last accessed on 20 September 2017) pp.2-20; here p.9.

${ }^{6}$ Garton-Ash reasoned: 'Unlike Britain, Germany also has a relatively responsible popular press. (...) Precisely because Germany once had the diabolic epitome of populist xenophobia, it is now most resistant to it.' Timothy Garton-Ash, 'For Europe's sake, Angela Merkel must hold the centre ground', The Guardian, 22 December 2016, available at https://www.theguardian.com/commentisfree/2016/dec/21/berlin-christmas-market-attack-angelamerkel-germany-terror-liberal-europe (last accessed on 20 September 2017).
} 
showed the ambivalent feelings involved in playing host. The many displays of German Willkommenskultur (welcoming attitude in German culture) were soon tested by the events surrounding the 2015/16 New Year's Eve celebrations in Cologne and other German cities. Sexual assault of females allegedly perpetrated by men of mainly northern African appearance was initially underreported by German officials and the media. But these incidents later led to heated debates about residency rights of asylum seekers and irregular immigrants, even in mainstream media. It seemed to answer in the affirmative a question raised by the German weekly Der Spiegel on its cover just weeks earlier: Is Germany in danger of losing its core values? ${ }^{7}$ Is the core of its democratic and liberal tendencies still sufficiently supported by a stable, welleducated, well-travelled and well-meaning middle-class? Is Germany's centre drifting to the political right?

In a fortuitous coincidence, fact and fiction were presenting, at the time of greatest need, several conflicted but ultimately humanistic responses to problems so complex and supra-national, so large and complicated that solutions could only meaningfully be arrived at in small gestures and pragmatic actions; local and immediate, raw and unconventional. The retired professor Richard in Going, went, gone and Julius Reither, the equally erudite and comfortably retired book publisher in Kirchhoff's novella Encounter, feel compelled to adopt a paternal role for people in need, although their sense of obligation and duty seems difficult to sustain in view of institutional barriers and legal frameworks that foreground cold reality over any sentimentality.

Encounter ${ }^{8}$ focuses on Julius Reither, a retired publisher in his late sixties who lives in a serviced apartment complex in Germany's far south. His residence is staffed at night by migrant personnel with whom he talks occasionally. He describes them as the blond Bulgarian, Marina, always dressed a little too elegantly for her reception job, and a black Eritrean beauty of biblical grace and reserve called Aster. Reither appears as an old-fashioned male, whose life had only consisted of work until his sad realisation that there were more writers and books than readers in the world. His closest confidante and friend had been his one and only employee, but now he succumbs to the lure of one of his neighbours, Leonie Palm. The narrator adopts Reither's point of view, sexualising all his female encounters and reducing Marina and Aster to foreign nationals without last names; 'the Bulgarian' $(9,41)$, the 'Eritrean beauty' $(9,41)$. The latter's flight to Germany with the help of people smugglers on a boat across the Mediterranean is mentioned several times in passing (23), retold like an adventure story by those who have heard it from her, in a sensationalised manner, but without real empathy (39-42). Aster had helped jump start an old pick-up truck on many occasions in the deserts of Africa during her flight. She initially made it to Sudan's capital Khartoum, paying 200 dollars to get there, and worked day and night for an exploitative employer before being able to afford the next leg of her journey by truck, together with 30 others. That trip over sand and stone all the way to Libya cost 300 dollars and from there, after escaping abduction and paying another 500 dollars, she set off on a small, overcrowded boat headed for the Italian island of Lampedusa (41). When the engine failed, the boat drifted for days, before ultimately making it to Sicily's bay of Catania. Aster's story, as relayed to Julius by 'the Bulgarian' is an unwelcome distraction from his own affairs at this point and briefly delays his departure on a spontaneous night-time adventure with Leonie, whom he has met just an hour or so

\footnotetext{
${ }^{7}$ Alexander Neubacher, 'Eine verstörte Nation: Verliert Deutschland seine Mitte?', Der Spiegel, 51/2015, p.1.

${ }^{8}$ Bodo Kirchhoff, Widerfahrnis. Eine Novelle, Frankfurt: Frankfurter Verlagsanstalt, 2016. All in-text references to page numbers in square brackets refer to this edition.
} 
earlier. Indicating that the German couple themselves are on a kind of flight, Aster helps to start Leonie's ageing convertible, an action which sets them off on their excursion with a bottle of wine and the desire to see the sun rise over an Alpine lake.

Reither's life is depicted as self-centred and self-serving; this stereotypical smoking and reading intellectual is emotionally self-sufficient as long as his own creaturecomforts are satisfied. With his new love-interest, Julius recalls how to conjugate 'amare' in both Latin and German (65), and goes on to exercise the word in theory and practice. Their trip, originally planned as an escape from everyday boredom, inverts Aster's journey once she had reached Europe, leading them from Germany all the way to Sicily. While for those travelling the other way the hope for a better life and safety are paramount, Reither is reminded of the Latin his schoolteacher father taught him and becomes buoyed by the certainty of the promise: 'amavero', meaning, in the future perfect tense: I will have loved (81).

As the antiquated German noun of the title (Widerfahrnis) indicates, Reither does not seek out encounters and experiences or makes plans or decisions; instead things seem to happen to him. There are several instances during their journey south when he and Leonie come across the many irregular migrants moving ever northwards, but he does not allow their fate to touch him, nor does he draw Leonie's attention to them. At the railway station on the Italian side of the Brenner Pass, Reither sees a huge crowd of hundreds of people, carrying innumerable bundles and backpacks, blankets, people with caps and colourful headscarves, carrying everything imaginable. However, he says nothing to Leonie:

...what could he have said anyway, without distracting her. Just concentrate on the tunnel, Leonie, it goes down to one lane, but if you were to look to the right out of my window, you'd see what's coming our way, our future - he saw it this way himself for the first time, up until now he'd only read about it in his preferred newspaper, articles which he could believe in, the photos too... (63).

Further along he becomes aware of other travelling groups of refugees, noticing movement in the bushes, as if caused by animals, sheep or goats, but then realising that there are people gathered there, clasping their worldly goods (70). Speeding along on the autobahn, his attention is drawn by a collection of clothing in the shadows of the bushes that line the roadway, until he notices the dark faces and all the bundles and bags - they pass by in a flash, but he knows what he has seen (90). When they stop briefly to get some sleep and buy some supplies, he asks Leonie if she had seen the people camping amongst the bushes, and then wants to know if the car is locked reacting with suspicion and wariness (74-5). Returning with their shopping, they stumble upon a confrontation between a group of north African refugees and the German owners of a caravan. Leonie seems prepared to wade right into the situation, while Reither first has to draw breath, to weigh up what to do here and what to leave well alone (77). The caravan owners claim that the refugees have stolen their dog's food and say to Reither: 'They're all coming our way and then they'll take what they need. Do you want that?' (78). Reither's sympathy is aroused - but only extends as far as spontaneously handing the leader of the group most of the food they have just bought, and half of their water, and he avoids speaking to them or giving them money. For him this seems the sensible thing to do because 'that was good, that was sufficient, as they say' (78-9). Then he and Leonie just drive off, with the group of refugees, from that moment on apparently, out of sight and out of mind. 
The pair travels as far as Taormina, an ancient settlement with a well-preserved amphitheatre, the place where, in 1787, Goethe marvelled at Sicily's relative wilderness which contrasted strongly with the classical heritage of Magna Graecia. ${ }^{9}$ In Catania Julius and Leonie are followed by a young teenage girl in a ragged dress who tries to sell them a necklace with a metal shard as a pendant. She is unkempt, begging (129), and there are repeated hints that she is part of the irregular migrant underbelly in southern Europe. ${ }^{10}$ When a waiter wants to order this beggar and 'thief', as he calls her, away, Julius Reither spontaneously defends her: 'She belongs to us!' (136). It is only now that Reither and Leonie seem to engage on a deeper level with one of the refugees they encounter. Their defence of the girl only lasts until the police arrive and she flees, clearly lacking legal protection. She re-appears at their holiday flat and now the German couple take her in as their surrogate child (147). They feed and clothe her, before taking her off the island of Sicily with them in a futile and semi-criminal flight of their own. On the ferry to the mainland, the girl runs from her supposed liberators, her shard necklace badly slicing Julius' hand as he tries to hold her back. It is another irregular migrant, a black African, who finds the bleeding German and offers his help (203). This Nigerian refugee, Taylor, who has made it to Europe with his young wife and baby daughter, stitches up his hand and is in turn helped by Julius, who responds to Taylor's request to take the refugee family, 'without a roof over their heads, no bank account and no advocacy' (210), back with him to Germany. Julius Reither's behaviour in the preceding hours has discouraged Leonie from remaining with him. She decides instead to continue travelling, to explore the sights of Italy that she has not yet seen while she still has time, because, as the reader discovers, she is terminally ill. She farewells Reither, giving him her car and her apartment keys to the refugee family (222) and leaves them to their own devices. He is likely to return to his retirement 'idyll', with his new neighbours, whose illegal entry to Germany he now facilitates by an act of civil disobedience.

Kirchhoff's protagonists thus become fictitious examples of the civil disobedience explicitly called for by the real-life protest and activist group 'Peng!-Kollektiv', who produced an advertisement encouraging German holidaymakers to return from their stay in the Mediterranean with a refugee in their car: 'Support people on their way to a better future! / Unterstütze Menschen auf ihrem Weg in eine bessere Zukunft!' Aware that this would constitute a criminal act (assisting illegal entry / Beihilfe zur illegalen Einreise), Spiegel Online helped distribute it widely, the German weekly Die Zeit provided a column with legal advice from a Professor of Law and even the Bayrische Rundfunk, a radio station in notoriously conservative Bavaria, reminded its viewers and listeners that not so long ago people helping others to flee were

\footnotetext{
${ }^{9}$ Goethe re-reads the Odyssey in Greek and Latin en route.

${ }^{10}$ The girl's 'skin seemingly darkened by the name of the country, Morocco, Libya, Albania and wherever else there was a coast from where a boat could be boarded in the hope that it wouldn't sink and would reach the paradisiacal shore, (...) this was no normal girl, rather, she was a smooth customer, you didn't want to know where she had been...' (129); '... underpasses, clearly made for people, though more for the shady sort, even if you had to be careful using that word, but anyway, here they all stood, in the darkest part, talking and smoking, mainly Africans ...' (131); 'The police gave up the pursuit (...) and one turned to Reither and in broken English explained that girls like that are thieves, all of them, better to stay away from them...' (138-139); '... a trio of musicians emerged from the tunnel through which the girl had fled (...) easy to imagine a whole procession of beggar children following behind (them) ...' $(139,141)$; 'Two men came past (...) each with a white prayer cap and a gray robe, and the girl was suddenly invisible.' (144); 'Two men passed by again, both wearing long robes (made) a peaceful impression, just out on their evening walk, only (they) could have been murmuring about a plan to smuggle people, to rob, to murder, you just never know, you can only hope, hope, that they are what they seem to be.' (145).
} 
criminalised in the GDR, but were later rehabilitated and admired in the unified Germany.

Within the logic of Kirchhoff's narrative, the experiences of the road trip remain raw and undigested for Reither, bringing back memories of lost loved ones and offering him the opportunity to right historical and personal wrongs. Whether he can muster the selflessness required to do so long-term is questionable in view of his past selfcentred behaviour. The novella ends abruptly, with many questions unanswered and everybody's fate in limbo.

Through their actions that transcend the familial circles but remain vested in the private sphere, Julius and Leonie occupy the so-called 'third sector' of society. Distinct from government as well as business and industry this is the realm that has the potential to make or break a civil society. The protagonists exercise their will independently of the official policies and activities in relation to refugees and exemplify strong civic values in doing so. Their responses to their encounters constitute social capital that is seen as a vital ingredient for any liberal democracy. ${ }^{11}$

Civic duties and acts of disobedience also feature in Erpenbeck's novel, which has a focus on human encounters across generations and cultures, including, in many ways, the ongoing process of the unification of East and West Germany. ${ }^{12}$ Her protagonist, Richard, makes it clear that, even 25 years after the demise of the GDR, many of its citizens are still trying to arrive in Germany. Richard is one of them, and therefore vaguely understands what it must mean to have to leave everything behind and start again, like the refugees he encounters.

The novel uses the figure of the recently retired professor of classical philology as a vehicle of Germany's bürgerliche Kultur. His working life and his retirement have allowed this educated citizen to withdraw from the rest of society, his special area of interest being the classics and ancient history, but his encounters in the novel catapult him from antiquity to the present. Life in Richard's house on a lake on the outskirts of Berlin has become lonely, with his wife's death five years ago and his younger mistress having left him. Even the beautiful view of the lake, the shores on which he lives, has become torture since the drowning of a man who had been swimming there and whose corpse has still not been recovered. This one corpse is contrasted with hundreds of other bodies in the water: refugees, for whom the Mediterranean Sea has become a mass grave. In his initial fixation on the single dead person who has spoiled the lake and its cherished leisure opportunities for Richard and other residents, it becomes clear that the loss of one white Central-European life seems to be more significant and more burdensome than one hundred African lives.

On an extra-diegetic level Erpenbeck cites the day when nearly 400 people drowned near Lampedusa on 3 October 2013 as the inspiration for her text: this news story struck the author as 'novellenhaft', unique and like a bolt of lightning. 'At that time we were still unaccustomed to such news', it seemed 'a one-off event' of horrendous

\footnotetext{
${ }^{11}$ Robert D. Putnam, Democracies in Flux. The Evolution of Social Capital in Contemporary Society, Oxford: OUP, 2002.

${ }^{12}$ Jenny Erpenbeck, Gehen, Ging, Gegangen. Roman, München: Knaus, 2015, p.222. All in-text references to page numbers in rounded brackets refer to this edition.
} 
proportions. ${ }^{13}$ At that moment Erpenbeck wondered, 'What is happening with the survivors?' ${ }^{14}$ and began her own investigation. Her protagonist becomes her alter-ego, as Richard, like her, also feels compelled to act (in the sense of a 'one off' event). He has until now overlooked those who want to be seen. Preoccupied with his own thoughts, he had failed to see a demonstration by African refugees at the Alexanderplatz, despite being there at the same time. This is unbearable to him, precisely because of the protestors' slogan spelled out in broken English: 'We become visible' (27) - they want to be seen. The refugees are protesting for the right to stay in Germany and to be allowed to work, but refuse to give their names to the authorities. Richard finds it intriguing that the men want to become visible in public by not identifying themselves, as it reminds him of Odysseus calling himself 'Nobody' to escape from the cave of the Cyclops (31-32). At the same time, he realises his erudite comparisons are futile and inappropriate in view of the new realities. Indeed, Richard gradually realizes the irony of his ignorance of where Burkino Faso is, or what the capitals of Ghana, Niger, and Sierra Leone are, basic facts about where the asylum seekers come from, and yet he would have disapproved of any student who could not recite the first four lines of Homer's Odyssey in Greek (33).

So Erpenbeck describes how an educated citizen, who is not particularly principled, a little sexist, absent-minded and impractical, comes to reflect on his own racism, chauvinism and Euro-/Germanocentrism. As if he were still working in academia he embarks on a rigorous investigation, questioning the refugee situation and structuring it like a research project. He wants to find out what the refugees think and what has shaped them, creates a catalogue of questions - as is required for empirical research reads, consults history books, trying to understand colonial aspirations, before recognising their long-term effects, such as the arbitrariness of the colonial powers drawing straight border lines to mark off their territories on maps (66).

However, Richard's questions are banal and patronising and do not address the issues important to the refugees. He initially only sees things in black and white, black men and white sympathisers (44-45), recognises the Tuareg as a VW car model (67) rather than as a tribal group, and reaffirms his dichotomous views of the world of East and West, good and bad. Passages from literary texts occur to him involuntarily as he struggles to make sense of his encounters with the refugees. He calls some of the men, when he finally meets them, 'Tristan', 'Apollo' and 'Hermes', because 'Richard finds it difficult to remember the strange names of Africans' (84). All the black skin and black hair make it 'hard for Richard to remember who anyone is' (93). As such, he calls Raschid, 'the powerful man, who is obviously the one here who makes all the decisions' (60), 'the Lightning Thrower' because he reminds him of Zeus, the King of the Olympian gods. (115). Thus the expert on the works of Homer is stripped of his educated civil façade and unmasked as something of a philistine. ${ }^{15}$

Richard increasingly becomes aware of the gaps in his knowledge, and of the gravity of what the men have suffered. The difficult situation in which they now find themselves trapped, show them drowning in the complexities of German and European

\footnotetext{
${ }^{13}$ Jenny Erpenbeck, quoted in Denis Scheck, „Druckfrisch', ARD-Fernsehen, http://www.daserste.de/information/wissen-kultur/druckfrisch/videos/jenny-erpenbeck-gehen-ging-gegangen100.html (last accessed on 22 September 2017).

${ }^{14}$ Erpenbeck in Scheck.

${ }^{15}$ Cf. Ulrike Sárkány, 'Apoll und Tristan am Oranienplatz. Jenny Erpenbeck: Gehen, ging, gegangen', Norddeutscher Rundfunk - Kultur (16.9.2015), http://www.ndr.de/kultur/buch/tipps/Jenny-Erpenbeck-Gehenging-gegangen,erpenbeck120.html (last accessed on 22 September 2017).
} 
immigration and asylum laws. The African men are from a variety of countries, and have escaped conflict, discrimination, poverty and slavery to seek asylum in Europe, after surviving horrific journeys in small boats across the Mediterranean, journeys in which many of their fellow travellers have drowned or died of thirst. They all have in common that they have arrived in Italy, or were rescued by the Italian coast guard and navy vessels, and have since made their way to Germany. There they have found themselves in legal limbo, due to European Union law, the so-called Dublin Regulation. According to Dublin II (as it is referred to in the novel, though it has since been replaced by Dublin III), refugees and asylum seekers are the responsibility of the member state where they first arrived and were fingerprinted ${ }^{16}$ to process their claims for asylum. The regulation has been criticised for unfairly burdening the countries on the periphery of the EU, particularly along the Mediterranean coastline, because this is where most of the refugees arrive. While they may move on to other countries within the EU, the Dublin Regulation (sometimes called the Dublin procedure) requires that they must be returned to the first country in which they arrived for processing. The Africans in the novel cannot have their claim for asylum processed in Germany, so they cannot be considered refugees and are ineligible for the rights and concessions that asylum seekers are usually accorded, including the right to seek work.

When Richard helps the migrants master the German language and encourages them to tell their stories, he unwittingly cements their fate, as all of them thus recall their arrival in Italy. He recognises the futility of the situation as much as his own impotence, ignorance and irrelevance. As a field researcher, meeting refugees with questionnaire in hand, he is a cliché of the Faustian type. The archetypal Germanness is also foregrounded in Richard's name (the reader never learns his last name). It is derived from the Germanic 'richi' / rich, powerful and 'hard' / strong, thus Richard means 'rich and powerful'. His down-to-earth attitude, the conservatism of his values and his awareness of the Nazi past make him a symbol of his country. From a humanism that is reinforced by his education, the link to Aristotle's idea of civil society, i.e. of koinōnía

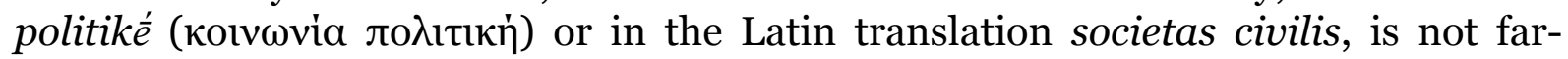
fetched. Richard creates a community of sorts in his house, where he lives by, and promotes his norms and civic values, offering asylum to more and more refugees.

To them Richard offers hospitality, as he knows this attitude from the Odyssey as well as from Tacitus, where it is considered in the Germanic sense a sin, to close your house, (...) between host and guest there is no difference between mine and his' (309-10). Richard must now interpret what he has known so far only as a literary motif. However, it is not just about Richard as a host, but rather about hospitality and asylum as an actual institution. The borders of the state as an asylum-granting entity and the conditions of the granting of asylum thus become the subject. Who should be admitted according to the Dublin Regulation? Richard responds to the failure of EU politics and institutions with his own initiative, where the responsible citizen even assumes responsibility, and is mobilised to bring the issue to public notice for the benefit of the community.

Richard recognises the perfidious logic of 'Dublin II', according to which those countries that have no Mediterranean coastline are not responsible for these boat people. His gradually growing interest thus ultimately tends towards exercising

\footnotetext{
${ }^{16}$ For the European fingerprint database established by the EURODAC Regulation, which enters the fingerprints of all asylum seekers into the one system, see https://ec.europa.eu/home-affairs/what-wedo/policies/asylum/identification-of-applicants_en (last accessed on 22 September 2017).
} 
unconditional hospitality, especially since the official position (government/statutory) is increasingly perceived as contrary to his emotional logic. ${ }^{17}$

While in Kirchhoff's novel is it the metaphor of the protagonists searching and therefore 'moving' and 'driving', in Erpenbeck's novel it is the irregular verb 'to go' which is synonymous with the refugee's fate; their past, as well as their future and their present. The novel's title, which conjugates the verb, is taken up several times in the novel, for example, in language classes. Even though the African refugees are legally only temporarily 'tolerated', they are given German lessons and made to conjugate over and over the verbs of motion, including 'to go'; at each new place their existence is being tolerated, until the order to go, i.e. to leave the country, is officially delivered to them. Even then the paradox remains: 'Where does someone go who does not know where he is supposed to go?' Erpenbeck states this question twice on two otherwise empty pages. However, there is no answer.

Those who have survived the crossing of the Mediterranean are made to 'drown in a sea of files' (310), Richard thinks, and 'if it is not due to their own merit that life is so pleasant for them (Richard's neighbourhood and circle of friends), it is also not the fault of the refugees that they have had it so bad. It could just as well be reversed' (120). Thus Richard admits the pure 'luck of the parallel universe' (152) and reflects on the ambivalences of his own existence. ${ }^{18}$ Richard's name is almost an anagram of that of one of the refugees: Raschid. It is deliberate that they are almost interchangeable. The fate of the individual is the result of many small coincidences and the role of host and guest could just as well be reversed.

Richard is carefully working towards a more nuanced picture of the world and trying to think, see and talk more carefully. As such, 'Maybe' is the first word of a novel (9) that raises more questions than it provides answers. Cautious formulations describe the circumstances, but also imply the opposite or negate them, and this determines the ways of thinking and language style of the inner monologue, as well as the reflections of the dialogues and theoretical discourses. Kirchhoff shows that chance alone is the deciding factor of the fate of those refugees who will drown at sea today somewhere between Africa and Europe, and those who won't.

Jenny Erpenbeck has stated: 'I have talked to refugees and processed their stories in the book, but the novel is not documentary'. ${ }^{19}$ Still, with its quasi-documentary-style passages, Going, went, gone contributes to a deeper and empathetic understanding of the current refugee debate and provides ample evidence that a rethinking of government policies is necessary. Richard stands for a reality in Germany's middleclass. He is well-off and resilient, yet overwhelmed like many in his homeland, because he is playing host out of necessity and as a response to an outrageous incident. But he is only a temporary surrogate father and a temporary host. The fate of a country, with all its ambivalences and contradictions, is reflected in his situation, because hospitality

\footnotetext{
17 'The written laws come as a society becomes more developed, at the point of common sense.' (308f.) ${ }^{18}$ Cf. Sibylle Bierer, 'Jenny Erpenbecks Gehen, ging, gegangen. Gestrandet in der Warteschlaufe', Neue Zürcher Zeitung, 10.10.2015, http://www.nzz.ch/feuilleton/buecher/gestrandet-in-der-warteschlaufe-1.18627304 (last accessed on 22 September 2017).

19 Jenny Erpenbeck, quoted in Sebastian Naumann, „Flüchtlinge sind zu Freunden geworden', Berliner Zeitung, 11. Oktober 2015, http://www.bz-berlin.de/kultur/literatur/jenny-erpenbeck-fluechtlinge-sind-zu-freundengeworden (last accessed on 22 September 2017).
} 
is a simulacrum. The refugees are again made to move on in a vicious circle of 'going, went, gone, going...'.

Indeed, whether enacted based on careful humanist considerations, as in Richard's case, or as an impulsive self-serving response, as exemplified by Julius, hospitality is complex. With their open endings both texts deny the reader any sense of a happy conclusion, instead highlighting the fact that answers have not yet been found, not in Germany and not in the EU. Merkel may have left the border open for many varied ${ }^{20}$ and valid ${ }^{21}$ reasons, but the legal framework of the $\mathrm{EU}$ and the not quite legal responses by nation states and individuals have created a complex and volatile situation that requires both humanitarian ${ }^{22}$ and practical, ${ }^{23}$ as well as geopolitical and legal ${ }^{24}$ resolutions. Many admirers and critics alike have conceded that 'the Chancellor has put all her trust in the people. Without the thousands of volunteers, the state would have collapsed'. ${ }^{25}$ For the most part, Germany's population understood the historical dimension and the need for their explicit or implicit cooperation and, indeed, action.

In the summer of 2015, men like Julius Reither and Richard, and women like Leonie dominated the public discourse of the broader middle class. Erpenbeck's book captures the mood of the time in Germany's capital, while Kirchhoff uses the figures of German tourists in Italy as witnesses to an ongoing situation, one that keeps developing. Dublin I, II and III, which have made it virtually impossible for the average refugee to ever reach Germany legally (the only option being to land on German soil by plane, or along its short coastline on the North Sea, coming directly from a centre of conflict), demand a re-thinking of European law and politics. Although neither Erpenbeck nor Kirchhoff are condoning illegality, they certainly help in exploring the human condition with regard to what goes into making laws and what makes people ignore borders. Both manage to show that the refugee situation moves the strong, stable, conservative, white (and still largely male-dominated) middle-class in a country that prides itself on its

\footnotetext{
${ }^{20}$ On 21 August 2015 Angelika Wenzl, the executive senior government official of the Federal Office for Migration and Refugees (Bamf), sent out an internal memo titled 'Procedural arrangement for the suspension of the Dublin procedure for Syrian refugees'; i.e. Syrians applying for asylum in Germany will no longer be sent back to the country where they first set foot on European ground. This memo ended up in the hands of the media. To this day those in management positions at the Federal Office do not know how this could have happened. As enquiries mounted, , the Bamf press office went on the offensive and tweeted at 1.30pm on 25 August: 'The \#Dublin procedure for Syrian citizens is at this point in time effectively no longer being adhered to.' On the Balkan route the Tweet spread immediately; it was considered an invitation. Before the Tweet nearly all of the refugees were registering in Hungary. Now almost no-one is anymore. The Hungarian ambassador in Berlin inquired with the Interior Ministry how things stood legally. They were unaware of the Tweet and were at a loss to explain the situation.' Angelika Wenzl, Regierungsdirektorin im Bundesamt für Migration „August 25, 2015, at 4:30 a.m.: The BAMF confirms via Twitter (in German): 'We are at present largely no longer enforcing \# Dublin procedures for Syrian citizens.' The tweet goes around the world thousands of time. Neither Angela Merkel nor Chancellery Minister Peter Altmaier, her chief of staff, know about it.' http://www.zeit.de/politik/deutschland/2015o9/angela-merkel-refugees-crisis-chancellor/seite-4 (last accessed on 22 September 2017).

${ }_{21}$ 'Two days before the lifeless body of a three-year-old boy was found on a Turkish beach, red t-shirt, face turned downwards - drowned in the Mediterranean Sea whilst fleeing towards Europe. Eight days before a truck with 71 corpses on board was discovered in the emergency lane on the side of the A4 autobahn: 59 men, eight women, four children; all had suffocated. And then there are the pictures of the railway station in Budapest, they've been on German TV for days. On the preceding day the Hungarian Prime Minister Viktor Orbán had claimed that the refugee crisis was not a European problem, but a German problem.' http://www.zeit.de/2016/35/grenzoeffnungfluechtlinge-september-2015-wochenende-angela-merkel-ungarn-oesterreich/seite-2 (last accessed on 22 September 2017)

${ }^{22}$ Cf. Miltiades Otulios, 'Die Grenzen der Menschlichkeit', in: Kursbuch, 183 (2015), pp.75-88.

${ }^{23}$ Gabriele Gillen, 'Wo beginnt die Festung Europas? Eine Reise durch Köpfe und Kontinente', in: Anja Reschke (ed.), Und das ist erst der Anfang. Deutschland und die Flüchtlingskrise, Reinbeck: Rowohlt, 2015, pp. 166-183. 24 Peter Müller, Organisierte Verantwortungslosigkeit. Die EU und die Flüchtlinge, in: Anja Reschke (ed.), ibid, pp.262-274.

25 Tina Hildebrandt and Bernd Ulrich, 'In the eye of the storm', http://www.zeit.de/politik/deutschland/2015o9/angela-merkel-refugees-crisis-chancellor/seite-5 (last accessed on 22 September 2017).
} 
stability; ${ }^{26}$ indeed the refugees in both books have the potential to change these men for the better by re-activating their dormant yet still strong humanitarian values over self-interest and hedonism.

Erpenbeck and Kirchhoff show how literature is able to reflect on the intimate exchanges that result from policies and maybe even encourage empathy and social change. They shine a light on different segments of society that want to define themselves as 'civil' and what this means. With new policies and practices emerging every day, this will remain a line of inquiry or an ongoing issue of definition for some time to come.

\footnotetext{
${ }^{26}$ Christian Jakob, 'Die Bleibenden. Flüchtlinge verändern Deutschland', Aus Politik und Zeitgeschichte. Zufluchtsgesellschaft Deutschland, 66. Jahrgang, 14-15/2016, pp.9-14.
} 